\title{
Navigating Reform in Contested Spaces: Reflections on not-for- profit sector regulatory reform in Australia, 2010-2013
}

Krystian Seibert ${ }^{1}$

\section{Introduction}

Historically, the not-for-profit (NFP) sector in Australia has not generally benefited from any strategic and wide-ranging NFP sectorspecific regulatory reform. Although over the years certain subsectors have benefited from particular reforms, there has been a clear lack of broad-based and comprehensive reform focusing on the key structural components of NFP regulation.

At the Commonwealth level, where regulation of the NFP sector has generally been focused on taxation matters, reforms have mostly been ad hoc and piecemeal, resulting in a taxation framework that is extremely complex and in some respects inequitable ( $\mathrm{O}^{\prime}$ Connell 2008: 17; Treasury 2013: 22).

1 The author thanks Professor Ann O'Connell, Professor Myles McGregor-Lowndes OAM, Mr Robert Fitzgerald AM and Ms Susan Pascoe AM for their comments on a draft version of this chapter. The chapter reflects the author's own views and any errors are the author's. 
The situation at the state and territory level is little different. This is most obvious in the case of fundraising regulation, which is fragmented and inefficient (Productivity Commission 2010: 138). Although fundraising regulation is reviewed from time to time, there has been little progress towards delivering widespread improvements, let alone any national consistency.

The establishment of the Australian Charities and Not-for-profits Commission (ACNC) was a major part of the NFP sector reform agenda that the Australian Government pursued between 2010 and 2013. It was an attempt to shift away from reform that was ad hoc and piecemeal or lacked substance and demonstrated a certain level of government indifference. With a specific focus on the NFP sector and charities in particular, it was strategic in nature and involved comprehensive and wide-ranging change rather than just tinkering around the edges.

At the time of the ACNC's establishment, former Assistant Treasurer David Bradbury (2012c) described the reform process in the following way:

The establishment of the ACNC is the key component of the Gillard Government's objective to deliver smarter and more effective regulation of the NFP Sector.

The ACNC is future-focused, structural reform, which the NFP Sector has long called for and has been recommended by review after review.

As the NFP sector grows, it is critically important to support the sector through smarter regulation. This involves designing a regulatory framework which is suited to the NFP sector and addresses flaws in the current approach to NFP regulation.

This is not to say that the reform process was perfect, or that the outcome met the expectations of all stakeholders in full. That would be an impossible task, and, as with any new regulatory framework, there are often aspects that require 'tweaking' after the initial implementation phase has passed. Nor is it to say that the reform process addressed all of the wide variety of challenges confronting the NFP sector, which are the subject of recommendations in the Productivity Commission's 2010 report Contribution of the Not-for-profit Sector. The establishment of the ACNC was never put forward as a solution to all these challenges. 
In this regard it is also important to emphasise that the ACNC reform process is ongoing, and will be until the elusive goal of a fully national approach to areas such as fundraising regulation is achieved.

As an adviser to the former Assistant Treasurer during 2012 and 2013, I was closely involved with the establishment of the ACNC and associated aspects of its regulatory framework such as its governance standards and financial reporting arrangements. My role included oversight of the development of the ACNC legislation and supporting the Assistant Treasurer's efforts to secure its passage through the Parliament. This involved working closely with officials within the Department of Treasury and engaging extensively with stakeholders within the NFP sector. The experience provided me with a unique perspective on the ACNC reform process 'on the inside'.

The purpose of this chapter, however, is not to recount the ACNC reform process in detail, nor to examine the background to the process. This is done well elsewhere (see, for example, Pascoe forthcoming; O'Connell et al. 2013). Nor is the purpose to examine the 'politics' of the process, including subsequent uncertainty about the ACNC's future after the 2013 election. Rather, the aim of this chapter is twofold. First, to illustrate why the ACNC reform process was a unique example of cross-sector working, which is the focus of this edited volume. Second, to reflect on the key insights from this process, which might inform future regulatory reform efforts, regarding regulatory reform as it relates to the NFP sector and beyond. These reflections are based on my own experiences and my discussions with the many stakeholders with whom I worked as part of the ACNC reform process.

\section{The ACNC reform process: $A$ unique case study of cross-sector working}

As pointed out above, Australia's regulatory framework for the NFP sector has generally been characterised by a lack of strategic and wide-ranging reform. Where reform has occurred, it has largely been ad hoc and piecemeal. Reforming such a regulatory framework in a more strategic manner was a complex undertaking. This complexity, together with other unique and significant characteristics, makes it an interesting example of cross-sector working. These characteristics are 
discussed below and provide some useful context for the 'key insights' from the ACNC reform process that are examined in the following section of this chapter.

\section{Focus, breadth and complexity}

The establishment of the ACNC was the largest and most complex structural reform experienced by the NFP sector in Australia (and, in particular, the charitable sector, which forms part of the broader NFP sector).

Although reforms such as the introduction of Australia's Goods and Services Tax (GST) in 2000 had a big impact on charities and other NFPs, the GST was an economy-wide reform and not specifically focused on charities.

Charities in certain subsectors have certainly participated in large and complex reform processes. For example, disability charities are currently experiencing a major period of change with the introduction of the National Disability Insurance Scheme and its consumer-directed care model. However, these changes, as considerable as they might be, do not impact on or involve the entire charitable sector. That is one defining feature of the ACNC reform process: it was complex, and challenging at times, and it was focused on the entire charitable sector and therefore impacted on all charities. In this regard it is unique.

\section{A response to sector advocacy}

The ACNC reform process was also an interesting example of a regulatory reform process in that it involved establishing a regulator in response to prolonged advocacy by a large segment of those whom it would regulate. Advocacy in favour of regulation is not uncommon, especially where it can benefit certain actors in a regulated space to the detriment of other actors. But proactive advocacy in favour of establishing a regulator by a broad cross-section of those whom it would regulate is rarer-and rarer still where it involves a relatively large sector; at last count there were more than 53,000 charities in Australia (acnc.gov.au).

Many Australian charities and their peak representative bodies had been advocating for a national charities regulator for some time, and it was first recommended in 2001 by the Report of the Inquiry into the 
Definition of Charity and Related Organisations (Sheppard et al. 2001). Until 2011, however, there had been reluctance from government to pursue such a course of action, and it is reasonable to assert that had it not been for the advocacy of a broad cross-section of the charitable sector and its influence on the findings of subsequent reports such as the Productivity Commission's Contribution of the Not-for-profit Sector (2010), the establishment of the ACNC would not have occurred.

\section{Proactive reform to establish a facilitative regulator}

When the then opposition's Shadow Minister for Families, Housing and Community Services, Kevin Andrews, announced in June 2012 that a Coalition Government would abolish the yet to be established ACNC, he commented that ' $[\mathrm{n}]$ owhere has the mischief that requires this new monolithic regulatory structure been identified' (Andrews 2012). In one sense, Andrews was correct: the establishment of the ACNC was not a response to some sort of crisis of public confidence in Australian charities, such as that which has prompted the United Kingdom Government to give more powers to its Charity Commission (Chamberlain 2014).

But in another sense, the then shadow minister's comments overlooked the fact that reactive regulation in response to a crisis is not an ideal approach to developing regulatory policy. It can lead to kneejerk reactions involving disproportionate responses to real or perceived problems. Indeed, one rationale for the establishment of the ACNC was that it was meant to prevent such kneejerk regulation. The aim would be to try to avoid any crisis, rather than wait for one to happen, by proactively pursuing regulatory reform that would support the growth of Australia's NFP sector (Bradbury 2012c).

In this regard, the ACNC reform process intended to establish a 'facilitative' regulator. Facilitative regulation can mean different things to different people, but it is most commonly used to describe a regulator which focuses on not only enforcing regulations but also supporting those it regulates to assist them to meet their regulatory obligations. This is, however, a relatively narrow definition of the term. For the purposes of this chapter, 'facilitative' is used in a broader sense, describing a regulator which is established to foster 
or nurture the sector it will regulate. In so doing, the regulator can support organisations within the sector to achieve their objectives and maximise their contribution to the common good.

This facilitative role is a key purpose of the ACNC regulatory framework and is codified in the second object of the Australian Charities and Not-for-profits Commission Act 2012 (ACNC Act), 'to support and sustain a robust, vibrant, independent and innovative Australian not-for-profit sector'. This is reinforced by some of the matters the ACNC Commissioner must have regard to in exercising their powers and functions under the ACNC Act, contained in Sections 15-10 (d) and (h), such as 'the maintenance and promotion of the effectiveness and sustainability of the not-for-profit sector' and 'the unique nature and diversity of not-for-profit entities and the distinctive role that they play in Australia'.

In The Regulation of Organised Civil Society, Garton (2009) dismisses the importance of such 'less tangible' reasons to regulate civil society organisations including charities. Garton cites other more important reasons such as the need to prevent anticompetitive practices, the need to coordinate the sector, the need to respond to philanthropic failures, the need to ensure accountability and the need to prevent the erosion of key civil society organisation characteristics (2009: 119). While a desire to promote accountability and transparency certainly formed part of the motivation for the establishment of the $\mathrm{ACNC}{ }^{2}$ especially within the government, even this desire was framed within a context of establishing a 'facilitative' regulator, with the then assistant treasurer stating in his second reading speech for the Australian Charities and Not-for-profits Commission Bill 2012 (ACNC Bill) that '[e]nsuring that the sector can consolidate its standing in the community through enhanced transparency and accountability is essential to its ongoing growth and sustainability' (Bradbury 2012b).

Therefore, based on the experience of the ACNC reform process, Garton is somewhat unwise to dismiss the significance of supposedly less tangible reasons to regulate the charitable sector, such as a desire to foster or nurture the sector. The intention to establish a facilitative regulator had implications for the nature of the cross-

2 See ACNC Act (s. 15.10[b]). 
sector collaboration involved during the ACNC reform process. This is a particularly relevant factor in the case of a number of the 'insights' discussed in the next section of this chapter.

\section{Contested reform in a highly charged political environment}

Although it is not the purpose of this chapter to examine the politics of the ACNC reform process, it is nonetheless important to highlight the broader political context in which the reform process occurred. The establishment of the ACNC took place during the Forty-Third Parliament (2010-13), which had a number of notable characteristics, including the relative instability associated with minority governments, which, although common in some other countries, are quite rare in Australia, especially at the federal level.

Overlaid on to this was the particularly adversarial nature of political engagement between the government and the opposition during this period. By its very nature, our parliamentary system is adversarial, but few would disagree with the conclusion that the Forty-Third Parliament was even more so than others. This particularly adversarial nature of political engagement was also witnessed in the context of the ACNC reform process - the establishment of the ACNC was a contested space, strongly opposed by the opposition. One need only review the Hansard transcripts of the debate on the ACNC Bill 2012 to see a number of heated exchanges that took place as the Bill and its associated ACNC (Consequential and Transitional Provisions) Bill 2012 were debated and ultimately passed. Progressing reform in such circumstances becomes even harder, especially when the numbers are so finely balanced in the Parliament and there is no prospect of support from the opposition. In spite of this, the ACNC Bills ultimately did become law.

\section{Successful cross-sector working}

The establishment of the ACNC was a large and complex structural reform that can be regarded as a success. Of course, this depends on how you define success. 
For the purposes of this chapter, it is regarded as a success first because the ACNC was established. This is an achievement in itself because it was a very complex reform involving a diverse range of stakeholders both within and beyond the charitable sector. Furthermore, this reform was pursued in a highly charged political environment and subject to strong political opposition, as discussed above.

Second, it is regarded as a success because of the broad support for the ACNC as reported in published surveys. The Pro Bono Australia State of the Not for Profit Sector Survey (2015) found that nearly 60 per cent of respondents preferred the ACNC to be the charities regulator, with 30 per cent preferring co-regulation, 7 per cent preferring selfregulation and only 5 per cent preferring the Australian Taxation Office (ATO). Notably, 80 per cent of respondents recognised the ACNC's importance in developing a thriving Australian NFP sector (Pro Bono Australia 2015).

This is not to assert that the ACNC's work is complete. Indeed, part of the promise of the ACNC relates to streamlining the regulatory framework for the charitable sector. The regulation of charities comes from many sources, including the Commonwealth and the states and territories. In the words of the Productivity Commission (2010: xxiii), this regulation is 'complex, lacks coherence, sufficient transparency, and is costly to NFPs'.

The ACNC has much work ahead of it, and much expectation riding on it. The announcement by the Australian Government of its decision to retain the ACNC (Porter and O'Dwyer 2016) will greatly assist to progress this work.

The success of the ACNC reform process involved cross-sectoral collaboration between government and stakeholders from the NFP sector and beyond. This included multiple government agencies such as the Treasury, the ATO and the Department of the Prime Minister and Cabinet, as well as the ACNC Implementation Taskforce. It involved a diverse range of charities including social welfare, religious, arts, environmental, international development and philanthropic organisations - as well as their various peak bodies. It also involved the professional advisers to these organisations such as accounting and law firms, peak bodies representing accountants, company directors and company secretaries as well as academic experts and 
researchers. All of these actors contributed their effort and expertise, and the effectiveness of this cross-sectoral collaboration was crucial to the success of the ACNC reform process.

\section{Reflections on the key insights from the ACNC reform process}

As discussed above, the ACNC reform process had a number of unique and significant characteristics that make it an interesting example of cross-sector working.

Structural reform is generally difficult to deliver; but despite various challenges and the fact that the ACNC is effectively still a work in progress, it is a structural reform that was delivered. There are a number of key insights from the ACNC reform process that are worth reflecting on to inform future regulatory reform efforts. Many of these insights relate to factors that were pivotal in achieving such major reform in a relatively short time.

\section{Demonstrating an intention to proceed with a new approach to collaboration and engagement}

The ACNC reform process was underpinned by an intention to proceed with a new approach to government and NFP sector collaboration and engagement. This approach was formalised in the National Compact, which had as one of its 'shared principles' an aspiration to build 'a relationship between the government and the sector based on mutual respect and trust' (Department of the Prime Minister and Cabinet 2011: 7). The shared aspiration for the relationship between the government and the NFP sector involved a commitment to work together respectfully, based on mutual understanding, and to communicate openly with each other.

Traditionally, there has often been a relationship of mistrust between the NFP sector and government. It is inevitable, and perhaps even necessary, to have a degree of tension between the two sectorsespecially given that a key role of the NFP sector is to undertake advocacy, and this means that the sector (or parts of it) and 
government will at times disagree on certain policy questions and have different views of how best to address particular social, economic and environmental challenges.

The widespread use of so-called gag clauses in Commonwealth funding agreements with NFP organisations under the Howard Government was an example of a policy that indicated a certain mistrust of the NFP sector within government, but also bred mistrust of the government within the NFP sector. Given this relationship of mistrust, some form of circuit-breaker was needed, and it is arguable that setting out shared principles and aspirations in a document such as the National Compact provided this.

There were tangible acts by the government, even before the National Compact came into force, demonstrating a desire to move in this direction. An example is the removal of gag clauses from Commonwealth funding agreements with NFP organisations in 2008 (Pro Bono Australia 2008). Such a commitment to proceed with a new approach to government and NFP sector collaboration and engagement was a prerequisite to the ACNC reform process. As discussed in the previous section, the establishment of the ACNC was not precipitated by any crisis of public confidence in Australian charities. Rather, it was a reform advocated for by the NFP sector, and hence it required not only the consent but also the support of the soon to be regulated sector to achieve the reform outcome.

So the National Compact played a critical role in facilitating the ACNC reform process - without both the government and the NFP sector 'starting afresh', it is highly doubtful the establishment of the ACNC would have been possible. Nevertheless, it is important to point out that during the ACNC reform process, the relationship between the government and the NFP sector was strained at times, and required recalibration.

On Senator Mark Arbib and then David Bradbury taking on the role of Assistant Treasurer in late 2011 and early 2012, respectively, there was a sense that the relationship was under some pressure. Some of the reasons for this are discussed in more detail below, but factors contributing to this included disagreements about the direction of the ACNC reform process, combined with short consultation times as well as some concerns about taxation measures the government was progressing alongside the ACNC reform process. In response to this, there was a 
renewed government focus on collaboration and consultation. This included increased engagement and involvement from the Assistant Treasurer and his office in the reform process, with support from the Minister for Social Inclusion (who had overall responsibility for NFP sector policy within the government) and his office.

\section{Timelines for reform balanced with the window of opportunity for reform}

Although lobbying for an independent regulator had taken place over many years, the actual establishment of the ACNC happened in a relatively short period.

Treasury (2011) published the Scoping study for a national not-forprofit regulator Consultation Paper in January 2011, the proposed establishment of the ACNC was announced on budget night in 2011 (Shorten and Plibersek 2011) and the ACNC was up and running by the end of 2012. While there was a desire to take advantage of the window of opportunity to progress reform, the pace of reform did present a challenge. This is evident from the chronology of ACNC reform process interactions in Table 7.1; the shaded areas indicate formal consultations undertaken involving submissions, face-to-face engagement or both.

Table 7.1: Chronology of the ACNC reform process

\begin{tabular}{|l|l|}
\hline 11 February 2010 & $\begin{array}{l}\text { Productivity Commission recommends a national Registrar } \\
\text { for Community and Charitable Purpose Organisations }\end{array}$ \\
\hline 9 August 2010 & $\begin{array}{l}\text { The Australian Labor Party commits to a scoping study to } \\
\text { establish a national not-for-profit regulator during federal } \\
\text { election campaign }\end{array}$ \\
\hline 21 January 2011 & $\begin{array}{l}\text { Treasury publishes the Consultation Paper Scoping study } \\
\text { for a national not-for-profit regulator }\end{array}$ \\
\hline 10 May 2011 & $\begin{array}{l}\text { Budget 2011-12 includes \$53.6 million in funding over four } \\
\text { years to establish the ACNC and to make related structural } \\
\text { changes in the ATO }\end{array}$ \\
\hline 4 July 2011 & $\begin{array}{l}\text { Australian Government announces that Robert Fitzgerald AM } \\
\text { will be the chair of the ACNC's Advisory Board }\end{array}$ \\
\hline 28 October 2011 & $\begin{array}{l}\text { Final Report of the scoping study released, and Susan Pascoe } \\
\text { AM appointed the chair of the ACNC Implementation Taskforce }\end{array}$ \\
\hline & Treasury publishes the Consultation Paper A definition of charity \\
\hline
\end{tabular}




\begin{tabular}{|c|c|}
\hline 8 December 2011 & $\begin{array}{l}\text { Treasury publishes the Consultation Paper Review of not-for- } \\
\text { profit sector governance arrangements }\end{array}$ \\
\hline 9 December 2011 & $\begin{array}{l}\text { Treasury publishes the exposure draft of the Australian Charities } \\
\text { and Not-for-profits Commission Bill and ACNC Implementation } \\
\text { Taskforce releases a discussion paper on the functions and } \\
\text { operations of the ACNC }\end{array}$ \\
\hline $\begin{array}{l}\text { January- } \\
\text { February } 2012\end{array}$ & $\begin{array}{l}\text { ACNC Taskforce conducts community consultations across } \\
\text { the country }\end{array}$ \\
\hline 1 March 2012 & $\begin{array}{l}\text { Australian Government extends the start date of the ACNC } \\
\text { to } 1 \text { October } 2012\end{array}$ \\
\hline 17 May 2012 & $\begin{array}{l}\text { Australian Government defers timing of proposed governance } \\
\text { and external conduct standards and financial reporting to allow } \\
\text { for further consultation }\end{array}$ \\
\hline 12 June 2012 & $\begin{array}{l}\text { ACNC Implementation Taskforce publishes its } \\
\text { Implementation Report }\end{array}$ \\
\hline 5-6 July 2012 & $\begin{array}{l}\text { Revised exposure draft of the ACNC Bill and accompanying } \\
\text { exposure draft of the ACNC Consequential and Transitional } \\
\text { Bill published and referred to the House of Representatives } \\
\text { Standing Committee on Economics }\end{array}$ \\
\hline 26-27 July 2012 & House of Representatives Committee public hearings on the Bill \\
\hline 15 August 2012 & House of Representatives Committee reports on Bill \\
\hline 23 August 2012 & $\begin{array}{l}\text { The ACNC Bill } 2012 \text { and its accompanying Consequential } \\
\text { and Transitional Bill introduced into the House of } \\
\text { Representatives and referred to the Senate Community } \\
\text { Affairs Legislation Committee and the Joint Committee } \\
\text { on Corporations and Financial Services }\end{array}$ \\
\hline 3 September 2012 & Joint Committee public hearings on the ACNC Bill \\
\hline 4 September 2012 & Senate Committee public hearings on the ACNC Bill \\
\hline 10 September 2012 & Joint Committee report tabled \\
\hline 12 September 2012 & Senate Community Affairs report tabled \\
\hline 18 September 2012 & ACNC Bills pass the House of Representatives \\
\hline 31 October 2012 & ACNC Bills pass the Senate \\
\hline 1 November 2012 & Senate amendments passed by the House of Representatives \\
\hline November 2012 & $\begin{array}{l}\text { NFP Sector Reform Council roundtable on ACNC Governance } \\
\text { Standards discussion draft released }\end{array}$ \\
\hline 3 December 2012 & Royal assent and ACNC commences operations \\
\hline 6 December 2012 & $\begin{array}{l}\text { Susan Pascoe AM appointed by the Governor-General as the } \\
\text { inaugural commissioner of the ACNC }\end{array}$ \\
\hline 10 December 2012 & ACNC officially launched by Assistant Treasurer David Bradbury \\
\hline 17 December 2012 & $\begin{array}{l}\text { Treasury publishes Consultation Paper Governance standards } \\
\text { for the not-for-profit (NFP) sector and draft financial reporting } \\
\text { regulations }\end{array}$ \\
\hline
\end{tabular}




\begin{tabular}{|l|l|}
\hline $\begin{array}{l}\text { December 2012 - } \\
\text { March 2013 }\end{array}$ & ACNC undertakes consultation on regulatory approach \\
\hline 8 April 2013 & Treasury publishes Charities Bill exposure draft \\
\hline 1 July 2013 & $\begin{array}{l}\text { ACNC Governance Standards and Financial Reporting } \\
\text { Regulations commence }\end{array}$ \\
\hline
\end{tabular}

Source: Adapted from ACNC (2013b).

Based on Table 7.1, between January 2011 and April 2013 (a little more than two years), there were 11 formal consultations undertaken involving submissions, face-to-face engagement or both. Some of these, particularly in December 2011, involved relatively short consultation time frames. This was in large part driven by the tight deadline for establishing the ACNC, which was originally meant to commence on 1 July 2012; and the tight deadline for establishing the ACNC was driven by a desire to take advantage of the window of opportunity to progress such a reform within the duration of the Forty-Third Parliament. However, it understandably led to some consternation among stakeholders, as evidenced by this statement from a stakeholder submission in response to the ACNC Bill exposure draft and governance arrangements discussion paper:

[W]e are concerned that the sector's hitherto support for the establishment of a national regulator is being undermined by the rapid process of drafting with key points of departure from the blueprint for a national NFP regulator set down by the Productivity Commission (2010); and by the inadequate amount of time provided for consultation on these changes, notably at a time when many organisations are closed or unable to consult with their members and boards on these important reforms. (ACOSS 2012: 3)

The pace of reform can be particularly challenging for NFP stakeholders, who might not have the resources available to business and other stakeholder groups but also often need to consult within extensive networks of member organisations. This was perhaps something that was not always fully appreciated, especially given the cumulative impact of multiple consultations over time, and the implications of this in terms of the resourcing of NFP stakeholders.

It quickly became apparent to the government that things needed to be slowed and therefore an extension was provided for the consultation process around the ACNC Bill exposure draft and governance arrangements discussion paper, and the date of the ACNC's 
commencement was pushed back to October 2012 (Arbib and Butler 2012). Further, not long after Bradbury took on the role of Assistant Treasurer in early 2012, a decision was made to phase in the ACNC regulatory framework, with the ACNC to commence operation in 2012 and the introduction of the ACNC's financial reporting and governance standards framework to be delayed by a year, commencing in 2013 (Bradbury and Butler 2012b).

The aim of this decision was to slow things a little and focus on progressing the primary foundational components of the ACNC regulatory framework before moving on to other components. It would not only allow for more time to consult on the ACNC's financial reporting and governance standards framework (discussed further below), but also provide more time for charities to transition into the ACNC regulatory framework and familiarise themselves with any new requirements. This staged approach was welcomed by NFP stakeholders (CSA 2012), and was a decision that assisted in holding together the reform process without losing reform momentum.

\section{Maintaining reform clarity and focus}

At the same time as the government announced its intention to establish the ACNC on budget night in 2011, it also announced a proposal to introduce a 'Better Targeting of NFP Sector Tax Concessions' (Better Targeting) measure (commonly referred to by stakeholders as the unrelated business income tax or 'UBIT') (Shorten and Plibersek 2011). This proposal would have restricted the use of charitable tax concessions for so-called unrelated commercial activities. Its announcement came as a surprise to the NFP sector and was the subject of considerable concern and uncertainty.

It is not the purpose of this chapter to discuss the merits or otherwise of the Better Targeting proposal in any detail (Turnour and McGregorLowndes 2012 provide a compelling argument for why Better Targeting was not necessary). However, with the benefit of hindsight, it is reasonable to conclude that progressing complex regulatory reform (the establishment of the ACNC) as well as contentious taxation reform (Better Targeting) alongside each other was not a good decision. 
Better Targeting presented various challenges on a number of levels. It challenged aspects of the National Compact - for example, the shared aspiration to 'communicate openly with each other', given that it was announced on budget night in 2011 with no prior consultation. This placed considerable strain on the 'refreshed' relationship that the government had sought to form with the NFP sector through the National Compact.

Flowing on from this, the presence of Better Targeting made progressing the ACNC reform process more challenging. This was not only because the uncertainty and concern around Better Targeting shifted some of the focus away from the positive objectives of the ACNC reform process, but also because the possible imposition of additional red tape through implementing Better Targeting contradicted one of the key objectives of the $\mathrm{ACNC}$, which was to reduce red tape over time. The announcement to implement Better Targeting represented a dilution of reform clarity and focus - and such clarity and focus are very important when seeking to undertake major structural reform such as the establishment of the ACNC. It was an unnecessary distraction, which shifted the focus off the main game.

On Bradbury taking on the role of Assistant Treasurer in early 2012, there was a conscious desire to maintain reform clarity and focus. A decision was taken to delay the introduction of Better Targeting for one year, and then again for two years in early 2013 (Bradbury and Butler 2013). This enabled the efforts of the government and NFP sector to focus on the ACNC reform process, with consideration of Better Targeting, including whether or not to proceed with it, deferred to a time after the ACNC was established.

There was clearly much happening. Given the importance of establishing the ACNC and some of the questions being raised about the Better Targeting proposal, the ACNC was given priority. The Better Targeting proposal was subsequently abandoned by the current government after the 2013 election.

\section{Seeking to coproduce reform}

In an environment characterised largely by constructive stakeholders who want to participate in the reform process in good faith, government should seek to coproduce reform where possible. This is particularly 
the case where, as with the establishment of the ACNC, the aim was to create a facilitative regulator, rather than one based on a presumption of wrongdoing and the need for heavy-handed compliance measures. It is also important in a reform context underpinned by an intention to proceed with a new approach to government and NFP sector collaboration and engagement - as evidenced in the National Compact.

Coproduction can come across as a buzzword - it sounds great and nobody can disagree with it - but the reality often does not live up to the ideal. However, the development of the ACNC governance standards provides a good case study of where this approach was adopted and proved to be beneficial.

As noted above, the introduction of the ACNC governance standards was delayed to allow for passage of the ACNC legislation and then to provide more time to consult on the content of the ACNC governance standards before they entered into force. The approach adopted in developing the governance standards involved preparing a discussion draft consultation paper outlining possible standards and the rationale for their inclusion. A NFP Sector Reform Council roundtable was then convened in Canberra, with council members and a wide range of other stakeholders and experts invited to attend. Attendees were provided with an advance copy of the discussion draft to formulate their views on it.

At the roundtable itself, the chair of the NFP Sector Reform Council led the discussion, which involved examining each draft governance standard and seeking the views and opinions of attendees. The discussion was very useful and informative and involved a number of changes to the draft governance standards (Treasury 2012). For example, initially there was a proposal to include a 'fit and proper' test for 'responsible entities' as part of the standards; however, the view of stakeholders at the roundtable was that this would be unworkable. Therefore, this proposal was not proceeded with. Other modifications and changes were also made before the discussion draft was finalised and a consultation paper was released for two months of public consultation (Bradbury and Butler 2012a). This process proved to be an effective way of introducing a degree of coproduction into the process of developing the governance standards. 
Too often consultation consists of government preparing a consultation document with little or no direct input from stakeholders at an early stage. But this kind of early engagement can not only identify issues that can be rectified before wider public consultation takes place, it also cultivates an atmosphere of openness as well as mutual respect and trust, which was a shared principle of the National Compact. It is also not particularly difficult to do, in that a discussion draft can be distributed and a stakeholder roundtable organised relatively easily. Even if all stakeholders did not necessarily agree with every aspect of the governance standards in their final form, there was recognition of the benefits of this process - as evidenced by this statement contained in a stakeholder submission in response to the discussion paper that was released for broader public consultation: 'We acknowledge that these standards have already been the subject of consultation within the industry and we believe that they have been significantly improved from an earlier draft' (AICD 2013: 1).

\section{The culture of the prospective regulator is critical}

By their very nature, regulators are vested with various powers and discretions. The key personnel of a regulator are given decision-making powers and their decisions shape how the regulator is perceived by those it regulates and by the broader community. These decisions can range from regulatory decisions - for example, about whether an organisation is registered as a charity or how noncompliance is addressed - to decisions about how to implement the regulatory framework, such as how it engages and consults stakeholders about its regulatory approach or the type and tone of the guidance it produces.

These are all matters of regulatory culture, which is driven by the staff of a regulator and in particular its leadership; when it comes to establishing a regulator with a good regulatory culture, people do matter. This is one critical component of a new regulatory framework that is basically impossible to codify in legislation. You can set out certain matters that the regulator must have regard to in exercising their powers and functions, such as those contained in Section 15-10 of the ACNC Act, but even that has limitations in terms of its impact on regulatory culture. 
This can be a source of some uncertainty among stakeholders. They might be satisfied with the legislative component of a regulatory framework, but then they might be uncertain and perhaps even concerned about how this legislation will be administered. Whether the regulator will operate with a heavy hand or be more of a 'light touch' regulator is an important question stakeholders ask themselves.

One way to address this uncertainty, and to provide a flavour of the culture of a prospective regulator before it has been formally established, is to effectively establish a 'regulator in waiting'. This is the approach that was adopted with the establishment of the ACNC. The assistant treasurer at the time, Bill Shorten, established the ACNC Implementation Taskforce in July 2011, with current ACNC Commissioner, Susan Pascoe, as the chair (Shorten 2011b), later to be referred to as the interim commissioner.

Just before this, in May 2011, it was announced that Robert Fitzgerald would be the first chair of the ACNC Advisory Board. Although the board would come into being only after the ACNC legislation was passed, the benefit of such an early announcement was that it enabled the Interim Commissioner and the taskforce to benefit from Fitzgerald's expertise and experience (Shorten 2011a).

The Interim Commissioner and the taskforce were charged with laying the groundwork for the ACNC, which initially involved extensive stakeholder consultation on matters such as the ACNC's proposed regulatory approach and other aspects of how the organisation would administer the ACNC legislation should it be passed.

To inform its work, the taskforce undertook extensive stakeholder consultation, which included one-on-one meetings with stakeholders, presentations at stakeholder events and hosting a range of open community consultations in early 2012. It released its Implementation Report in June 2012, summarising the outcomes of its consultations and setting out a roadmap for how the ACNC would operate (ACNC Taskforce 2012).

Through its work, the taskforce provided a clear indication to stakeholders of what to expect once the ACNC was formally established, and demonstrated that the ACNC reform process was truly about establishing a facilitative regulator. The taskforce embraced the principles of the National Compact in its own approach to engagement, 
and in this regard it played a critical role in holding together and maintaining confidence in the ACNC reform process. It is arguable that without the presence of the taskforce and the work it undertook, the establishment of the ACNC would not have been realised.

\section{NFP sector regulatory reform in a federation}

Regulation of the NFP sector is spread across both Commonwealth and state/territory governments. The Commonwealth, for example, regulates access to Commonwealth tax concessions and NFP companies limited by guarantee, while the states and territories regulate access to state/territory tax concessions, incorporated associations and fundraising. State and territory attorneys-general are also the nominal regulators of charitable trusts.

It is no wonder, then, that the Productivity Commission (2010: 138) concluded that this approach to regulation of the NFP sector is fragmented and inefficient. One of the rationales for the establishment of the ACNC was to address this complex regulatory mishmash and to drive a national approach to NFP regulation (Bradbury 2012a). However, the Commonwealth did not have the power to simply take over state and territory regulation, and therefore there were essentially two options available for implementing such a national approach.

Before committing to the establishment of the $\mathrm{ACNC}$, the Commonwealth could have begun negotiations with state and territory governments. The aim would be to obtain an agreement that addresses the various inconsistencies and complexities of NFP regulation and involves either the transfer of certain responsibilities to the Commonwealth and a new Commonwealth regulator or some form of alignment between state/ territory regulation and Commonwealth regulation. Alternatively, the Commonwealth could take the lead and establish the ACNC itself-and seek to engage with the states and territories parallel to this process.

If the first approach were adopted, it is probable that little progress, if any, would have been achieved. The political context within which the federation operates makes any reform through the Council of Australian Governments (COAG) very difficult. That is not to say that reform is impossible, as there are of course examples of reform efforts that have successfully progressed through COAG - just as there are many reform efforts that have failed. 
Therefore, the approach adopted was to establish the ACNC as a platform for delivering a national approach to NFP regulation - with significant reductions to regulatory burdens to occur over time with the cooperation of the states and territories (Bradbury 2012c). This is a regulatory reform approach that was based on the notion of 'build it, and they will come'.

Of course, there were some critics of this approach and, not surprisingly, some state and territory governments were not happy. But realistically, it was the only option available if there was to be any movement towards a national approach to NFP regulation. Some early signs were positive-for example, in 2012 the South Australian Government announced it would make amendments to its incorporated associations and charitable collections legislation to harmonise reporting requirements with the ACNC (Bradbury et al. 2012), followed by the Australian Capital Territory in 2013 (Bradbury et al. 2013).

Unfortunately, uncertainty about the ACNC's future has restricted its ability to achieve further progress with other jurisdictions. However, given the Australian Government's decision to retain the ACNC, there is now immense potential to obtain the agreement of other states and territories to align their regulatory frameworks with that of the ACNC. Evidence of this is that in 2015 the NSW Government expressed inprinciple support for aligning its fundraising regulation with the ACNC regulatory framework (OLGR 2015).

Although NFP sector regulatory reform is harder to progress in a federation, the argument against a 'build it, and they will come' approach to the ACNC reform process is weak. Some form of action with a firm objective in mind is better than endless negotiation with no realistic prospect of an outcome. Given there is now certainty regarding the ACNC's future, there is an opportunity to further test this conclusion and the effectiveness of the approach.

\section{Understanding that considering NFPs and charities as a 'single homogenous sector' is a challenge}

The NFP sector tends - as the name suggests - to be thought of as a single sector, when it really is a set of diverse subsectors unified under the principle that their purposes are not focused on private gain or, 
in the case of charities, are directed at public benefit. If we consider charities themselves, the diversity is considerable. Charities include large and small welfare organisations, universities, arts organisations, environmental organisations, large religious organisations and small community churches, charitable trusts and foundations, hospitals and aged care providers, housing cooperatives - and the list goes on.

These are all very different organisations. Each subsector has its own agendas, interests and institutional structures. Some might not even identify as being charities at all, despite being charities at law-for example, universities and some trusts and foundations. This challenges the notion that there is a coherent and homogeneous NFP sector with which the government can engage (Butcher 2015: 3).

The ACNC reform process effectively required maintaining a coalition of subsectors, which necessitated a very strong emphasis on stakeholder engagement but also an appreciation of how a common set of regulatory arrangements can have different impacts on different subsectors. This ultimately required modifications to the ACNC regulatory framework to seek to address these in part - for example, for small religious congregations, for non-government schools and for private ancillary funds. These modifications included targeted exemptions, tailored subsector-specific regulations and transitional arrangements. If a regulatory framework is sufficiently flexible, some of these different impacts can be managed administratively to minimise red tape, and the ACNC has been proactive in that regard-for example, in its work with non-government schools.

If we were to turn the clock back to before the ACNC reform process began, an alternative way of addressing this challenge might have involved phasing in the introduction of the ACNC regulatory framework to different parts of the NFP sector. For example, approximately 20 per cent of registered charities are either public benevolent institutions or health promotion charities (ACNC 2013a: 52). As a set of organisations, they would share relatively similar characteristics, although they will vary in size. They also benefit from the most generous set of tax concessions available to charities, including deductible gift recipient status and the fringe benefits tax exemption.

Perhaps these types of organisations could have been phased into the ACNC regulatory framework first, with others to follow over time. The option of phasing in such a manner was raised relatively early 
in the ACNC reform process (Not-for-profit Project 2011: 6). However, on balance, the flexible nature of the ACNC regulatory framework, as mentioned above, allowed for the tailoring of certain aspects of it to suit the unique situation and needs of particular subsectors within the NFP sector. The need for such flexibility does not appear to have been envisaged at the beginning of the ACNC reform process, but one lesson from the process is that when seeking to establish an interface with such a diverse sector, it is important to recognise the implications of this diversity for the development of the new regulatory framework, and manage these implications accordingly.

\section{Conclusion}

The establishment of the ACNC was a unique example of cross-sector working; it demonstrated that a diverse range of stakeholders from different sectors can work together collaboratively to implement a complex change. Like any reform process, the ACNC reform process was not perfect and had its challenges. Lessons were learnt along the way, and these insights are useful not only in the context of regulatory reform as it relates to NFP sector, but also might assist other regulatory reform efforts more broadly.

The ACNC reform process can be rightly described as a successin that the ACNC was established and it has built an excellent reputation as a regulator. However, success in this regard is not static, but rather dynamic. The mere existence of the ACNC at any given point is indeed a testament to the efforts of stakeholders, as described above. But it is the ACNC's performance over time that will provide a richer and more elaborate picture of its effectiveness as a regulator. The ACNC is a work in progress, and over time it will be judged against a number of standards. One of these includes its ability to deliver on the promise of a smarter national approach to NFP regulation. But it is important to note that the responsibility for delivering this is not the ACNC's alone; it is a regulator, not a policymaker. It will therefore rely on both federal and state/territory governments to swing their support behind efforts to streamline and simplify NFP regulation.

The Australian Government's decision to retain the ACNC provides an opportunity for the next stage of cross-sector working to begin. This will involve the ACNC, policymakers at a federal and state/ 
territory level and stakeholders across the NFP sector ramping up efforts to implement the reforms necessary to address the fragmented and inefficient approach to NFP regulation we still currently have in Australia - for which the ACNC provides the solution.

\section{References}

Andrews, K. 2012. The Coalition's approach to the charitable sector: Empowering civil society. Address to the Menzies Research Centre, Melbourne, 15 June.

Arbib, M. and M. Butler. 2012. Gillard government listens to sector on not-for-profit reforms. Media Release, 1 March. Parliament House, Canberra.

Australian Charities and Not-for-profits Commission (ACNC) Taskforce. 2012. Implementation Report. Melbourne: ACNC.

Australian Charities and Not-for-profits Commission (ACNC). 2013a. Australian charities 2013: The first report on charities registered with the Australian Charities and Not-for-profits Commission. Report prepared by Curtin University Not-for-profit Initiative. Melbourne: ACNC.

Australian Charities and Not-for-profits Commission (ACNC). 2013b. Not-for-profit Reform and the Australian Government. Melbourne: ACNC.

Australian Council of Social Service (ACOSS). 2012. Submission in Response to the ACNC Bill Exposure Draft and Governance Arrangements Discussion Paper. Sydney: ACOSS.

Australian Institute of Company Directors (AICD). 2013. Submission in Response to Development of Governance Standards Consultation Paper. Sydney: AICD.

Bradbury, D. 2012a. Australian Charities and Not-for-profits Commission passes Senate. Media Release, 31 October. Parliament House, Canberra.

Bradbury, D. 2012b. Parliamentary Debates. House of Representatives. 23 August 2012, 9722. 
Bradbury, D. 2012c. The NFP sector reforms: Moving towards smarter regulation. Address to the Thomson Reuters Not-for-profit Law and Regulation Conference, Sydney, 17 October. Available from: ministers.treasury.gov.au/DisplayDocs.aspx doc $=$ speeches/2012/011. htm \&pageID $=005 \& \min =$ djba\&Year $=\&$ DocType $=$ (accessed 7 July 2016).

Bradbury, D. and M. Butler. 2012a. Public consultation on ACNC governance standards and financial reporting regulations. Media Release, 17 December. Parliament House, Canberra.

Bradbury, D. and M. Butler. 2012b. Staging the introduction of regulatory reform for the not-for-profit sector. Media Release, 17 May. Parliament House, Canberra.

Bradbury, D. and M. Butler. 2013. Later start date for better targeting of not-for-profit tax concessions. Media Release, 31 January. Parliament House, Canberra.

Bradbury, D., M. Butler and A. Barr. 2013. ACT signs up to new charities regulator. Media Release, 11 March. Parliament House, Canberra.

Bradbury, D., M. Butler and J. Rau. 2012. Government delivering real reductions in red tape for charities. Media Release, 11 October. Parliament House, Canberra.

Butcher, J. 2015. 'The third sector and government in Australia: Not-for-profit reform under Labor, 2007-13.' Australian Journal of Political Science 50(1): 148-63.

Chamberlain, E. 2014. Charity commission: Power and responsibility. NCVO blog, 14 February. National Council for Voluntary Organisations, London. Available from: blogs.ncvo.org.uk/ 2014/02/14/the-charity-commission-power-and-responsibility/ (accessed October 2015).

Chartered Secretaries Australia (CSA). 2012. Finally some sense in regulatory reform of the NFP sector. Media Release, 18 May. Chartered Secretaries Australia, Sydney.

Department of the Prime Minister and Cabinet. 2011. National Compact: Working together. Canberra: Australian Government. 
Garton, J. 2009. The Regulation of Organised Civil Society. Oxford: Hart Publishing.

Not-for-profit Project. 2011. Submission in Response to the Scoping Study for a National Not-for-profit Regulator Consultation Paper. Melbourne: University of Melbourne.

O'Connell, A. 2008. 'The tax position of charities in Australia: Why does it have to be so complicated?' Australian Tax Review 37: 17.

O'Connell, A., F. Martin and J. Chia. 2013. 'Law, policy and politics in Australia's recent not-for-profit sector reforms.' Australian Tax Forum 28(2): 289-315.

Office of Liquor, Gaming and Racing (OLGR). 2015. Regulatory Impact Statement: Charitable fundraising regulation 2015-Report on public consultation. Sydney: NSW Government.

Pascoe, S. forthcoming. 'Sector advocated, sector supported: Australia's charity regulator.' In Regulating Charities: The Inside Story, eds M. McGregor-Lowndes and R. Wyatt. London: Routledge.

Porter, C. and K. O'Dwyer. 2016. Retention of the Australian Charities and Not-for-profits Commission. Media Release, 4 March. Parliament House, Canberra.

Pro Bono Australia. 2008. New Labor Government Removes 'Gagging' Clauses. Online article, 14 January. Pro Bono Australia, Melbourne. Available from: probonoaustralia.com.au/news/2008/01/new-laborgovernment-removes-gagging-clauses-2/ (accessed 6 July 2016).

Pro Bono Australia. 2015. State of the Not for Profit Sector Survey. Melbourne: Pro Bono Australia. Available from: probonoaustralia.com.au/wp-content/uploads/2016/02/2015_ sector_survey.pdf (accessed 6 July 2016).

Productivity Commission. 2010. Contribution of the Not-for-profit Sector. Canberra: Australian Government.

Sheppard, I., R. Fitzgerald and D. Gonski. 2001. Report of the Inquiry into the Definition of Charities and Related Organisations. Canberra: Australian Government. 
Shorten, B. 201la. Next stage for not-for-profit reforms announced. Media Release, 27 May. Parliament House, Canberra.

Shorten, B. 2011 b. Susan Pascoe appointed NFP reform implementation taskforce chair. Media Release, 4 July. Parliament House, Canberra.

Shorten, B. and T. Plibersek. 2011. Making it easier for charities to help those who need it. Media Release, 10 May. Parliament House, Canberra.

Treasury. 2011. Scoping study for a national not-for-profit regulator. Consultation Paper. Australian Government, Canberra.

Treasury. 2012. Governance standards for the not-for-profit (NFP) sector. Consultation Paper. Australian Government, Canberra.

Treasury. 2013. Fairer, Simpler and More Effective Tax Concessions for the Not-for-profit Sector: Final report of the Not-for-profit Sector Tax Concession Working Group. Australian Government, Canberra.

Turnour, M. and M. McGregor-Lowndes. 2012. 'Taxing charities: Reform without reason?' Taxation in Australia 47(2): 74-77. 
This text is taken from The Three Sector Solution: Delivering public policy in collaboration with not-for-profits and business, edited by John Butcher and David Gilchrist, published 2016 by ANU Press, The Australian National University, Canberra, Australia. 